\title{
Comparison Between Oviduct Fluid Protein And Oviduct Alephitelia Cell Supplementation In Increasing Oocytes Maturation Rate In Sheep
}

\author{
${ }^{1}$ Desi Wulansari, ${ }^{2}$ Viski Fitri Hendrawan, Aulia Firmawati, Yudit Oktanella \\ Department of Veterinary Reproduction, Faculty of Veterinary Medicine \\ Brawijaya University, M.T. Haryono No. 169, Malang \\ Correspondence email: desi_wulansari87@yahoo.com
}

\begin{abstract}
This study aims to increase fertilization rate through improved oocyte quality resulting from in vitro maturation results goats by means of Oviduct Fluid Protein (OFP) and Oviductal Ephitelia Cell (OEP) supplementation. Method used in this study consisted of two phases, 1) OFP collection from oviductal fluid and OEP from shredded oviductal tissue; 2). Oocyte maturation preparation and oocyte observations. It was found that supplementation of oviduct fluid in a concentration of $10 \%$ produced maturation rate through the observation of germinal vesicle breakdown $(\mathrm{GV})$, germinal vesicle breakdown GVBD, metaphase 1 (M1), and metaphase 2 (M2) that were significant compared to oviductal ephitelia cell supplementation in concentration of $10 \%$ in a maturation medium TCM 199.
\end{abstract}

Keywords: Oviductal Fluid Protein, Oviductal Ephiteli Cell, in vitro maturation, goat

\section{INTRODUCTION}

National Meat Self-Sufficiency Program launched by the Indonesian government in 2014 (PSDS-2014) is a common goal and became one of the main program of the Ministry of Agriculture to achieve domestic resources-based cattle origin animal food security, ${ }^{12}$ ones of which are goats and sheep. Activities to achieve meat self-sufficiency should be supported by appropriate institutional and proper reproduction technology as well, especially in artificial insemination and embryo transfer technology, which until then remains the flagship program of the Ministry of Agriculture of the Republic of Indonesia in improving meat selfsufficiency program in 2014. In vitro fertilization (IFV) technology is embryo production technology in artificial environment outside the body in a cell culture system, either using oocytes from living animals or from oocytes from sacrificed animals so that this technology may become an alternative of embryos production for the implementation of embryo transfer. ${ }^{1}$

Oocytes collected from ovaries are usually still immature oocytes, ${ }^{6}$ so they should be objected to maturation by placing the oocytes in appropriate culture medium and incubated at $37-38.5^{\circ} \mathrm{C}$ for 24 hours. Outcome of oocyte maturation using oocytes of sacrificed animals for embryo development up to now has not given satisfactory results. Important factors that relate to the success of oocyte maturation process are the handling of the oocyte and the composition of culture medium. ${ }^{13}$ The selection of appropriate medium is capable in supporting optimal oocyte metabolic activity and can improve oocytes survival. ${ }^{1}$

Hormones, growth factors, enzymes and several other compounds in the oviduct play an important role in oocyte maturation in vivo. ${ }^{8}$ In addition, there are cumulus oophorus cells role in oocyte maturation that strongly supports oocyte maturation. ${ }^{3}$ Cumulus oophorus acts as a connection between the granular layer cells with oocytes and allow removal of molecules 
from a population of granulosa cells into oocytes. ${ }^{4}$ Mature oocytes are characterized by the expansion of cumulus cells (cumulus oocyte complex: COC).

Improving oocytes quality from the results of in vitro oocyte maturation is expected to increase the success of in vitro fertilization ${ }^{9}$ so as to produce embryos in large quantities with good quality. Furthermore, an increase in the success of in vitro fertilization contributes to the production of embryos, sex selection (sexing), cloning, and genetic engineering. ${ }^{3}$

\section{METHODS}

The study was conducted to compare OFP and OEP supplementation on goat oocyte maturation medium. Materials used for this study included gentamicin sulfate, physiological saline, PBS, TCM-199, PMSG, hCG, Calf Serum (FCS), Penicillin Streptomycin, mineral oil (SIGMA), and aceto orcein. Instruments needed in this study were inverted microscope, laminar flow, syringes $18 \mathrm{G}$, erlenmeyer, scissors, tweezers, IV tubes, measuring cups, bowls nuclon, pasteur pipette, petri dish glass, baker glass, miliphore 0.2 um (Whatman, German Science), micropipette, 5\% CO2 incubator, and a Poly-L-Lysine-labeled glass object.

Collection of Oviduct Fluid Protein from oviduct fluid and Oviductal Ephitelia Cell from shredded oviduct tissue

Oviduct fluid collection and shredded oviduct tissue was done using goat oviduct from a slaughterhouse and transported to the laboratory at room temperature with physiological $\mathrm{NaCl}$ media. Only oviduct derived from animals sacrificed no more than 3 hours that could be used. The oviduct was then washed two times using physiological saline, placed in a petri dish and then dissected. Oviduct fluid collection was done in the following method: The liquid oviduct was collected from goat oviduct with follicle diameter between 3 $5 \mathrm{~mm}$ by means of flushing using TCM 199 stock solution of $0.5 \mathrm{cc}$ for $10 \mathrm{~cm}$ long oviduct. Results of the flushing were then centrifuged at $7000 \mathrm{rpm}$ for $10 \mathrm{~min}$ at $4{ }^{\circ} \mathrm{C}$ to remove cell debris. Then, the supernatant from the centrifugation was precipitated with ethanol. Obtained supernatant was mixed with ethanol at a ratio of 1: 2 . The mixture was then stored at $20^{\circ} \mathrm{C}$ overnight, and the next day it was centrifuged again at $3000 \mathrm{rpm}$. The pellet was the part to be used.

Shredded oviduct tissue collection to obtain oviduct epithelial cells was done by: 10 $\mathrm{cm}$ oviduct was dissected and finely shredded and then the finely shredded oviduct was added with the TCM 199 stock solution was added a solution of as much as $0.5 \mathrm{cc}$. Thereafter, the results of the shredding were centrifuged $7000 \mathrm{rpm}$ for $10 \mathrm{~min}$ at $4^{\circ} \mathrm{C}$ to remove cell debris. Supernatant results from centrifugation were precipitated with ethanol. Obtained supernatant was mixed with ethanol at a ratio of $1: 2$. The mixture was then stored at $20^{\circ} \mathrm{C}$ overnight, and the next day it was centrifuged again at $3000 \mathrm{rpm}$. The pellets was the part to be used.

Oocytes maturation

Oocyte collection was done by aspiration method of the follicle with diameter between 2 to $5 \mathrm{~mm}$ using a 19G-sized needle connected with $5 \mathrm{ml}$ syringe that had previously been filled in $0.5 \mathrm{ml}$ of Phosphate Buffered Saline (PBS). The collected oocytes were subsequently washed 2 times in PBS media and 2 times with TCM media, and subsequently were maturated in medium TCM-199 supplemented with 10\% FBS, 10 IU/ml PMSG, 10 $\mathrm{IU} / \mathrm{ml} \mathrm{hCG}$ and $100 \mathrm{IU} / \mathrm{ml}$ penicillin-streptomycin, then added with Oviduct Fluid Protein (P1), added with Oviductal Ephitelia Cell (P2), while the control group was not given any additions (P0). Oocyte maturation is done in a maturation medium in the form of drop each $50 \mathrm{ul}$ for 10-15 oocytes and covered with mineral oil in a $5 \% \mathrm{CO} 2$ incubator at $38^{\circ} \mathrm{C}$ for 24 hours. Only oocytes with a compact and homogeneous cytoplasm and had more than two layers of cumulus cells were used (Grade A and B). 


\section{RESULTS AND DISCUSSION}

\section{OEP and OFP supplementation in maturation media}

In this study a comparison was done on the treatment between OFP and OEP supplementation, each in a concentration of $10 \%$, and control group that did receive any supplementation. The aim was to observe comparison of maturation rate comparison between treatment groups. In supplementation process some things that should also be noted are sterility, the balance of nutrient composition and concentration of OFP and OEP addition because, based on previous studies, when OFP or OEP supplementation is given exceeding $10 \%$, it can reduce in vitro maturation and fertilization rate. This is because supplementation of more than $10 \%$ concentration may affect acidity level in fertilization and maturation media that may directly cause a decrease in the number of in vitro fertilization rate.

Maturation rate

After maturation at $\mathrm{CO} 2$ incubator for 24 hours, oocytes staining was done using aceto oersein to observe the degree of maturation of the oocytes using electron microscope with 400x magnification. Oocytes were evaluated to determine the level of maturation in each group (Table 1.).

Table 1. Maturation rate of germinal vesicle $(\mathrm{GV})$ phase

\begin{tabular}{l|c|c}
\hline \multicolumn{1}{c|}{ Treatment } & Repetition & GV Percentage \pm Standard Deviation \\
\hline KN (without treatment) & 15 & $33.33^{\mathrm{a}} \pm 5.19$ \\
\hline P1 (OFP 10\%) & 15 & $6.66^{\mathrm{b}} \pm 5.56$ \\
\hline P2 (OEC 10\%) & 15 & $26.66^{\mathrm{a}} \pm 5.09$ \\
\hline
\end{tabular}

Table 2. Maturation rate germinal vesicel (GVBD) phase

\begin{tabular}{lcc}
\hline \multicolumn{1}{c}{ Treatment } & Repetition & $\begin{array}{c}\text { Percentage GVBD } \pm \text { Standard } \\
\text { Deviation }\end{array}$ \\
\hline KN (without treatment) & 15 & $33.33^{\mathrm{b}} \pm 5.19$ \\
\hline P1 (OFP 10\%) & 15 & $13.66^{\mathrm{a}} \pm 5.56$ \\
\hline P2 (OEC 10\%) & 15 & $33.66^{\mathrm{b}} \pm 5.09$ \\
\hline
\end{tabular}

Table 3. Maturation rate of Metaphase 1 (M1) phase

\begin{tabular}{l|c|c}
\hline \multicolumn{1}{c|}{ Treatment } & Repetition & Percentage M1 \pm Standard Deviation \\
\hline KN (without treatment) & 15 & $20^{\mathrm{b}} \pm 5.19$ \\
\hline P1 (OFP 10\%) & 15 & $33.33^{\mathrm{a}} \pm 5.56$ \\
\hline P2 (OEC 10\%) & 15 & $20^{\mathrm{b}} \pm 5.09$ \\
\hline
\end{tabular}

Table 4. Maturation rate of Metaphase 2 (M2) phase

\begin{tabular}{l|c|c}
\hline \multicolumn{1}{c|}{ Treatment } & Repetition & Percentage M2 \pm Standard Deviation \\
\hline KN (without treatment) & 15 & $13.33^{\mathrm{b}} \pm 5.19$ \\
\hline P1 (OFP 10\%) & 15 & $46^{\mathrm{a}} \pm 5.56$ \\
\hline P2 (OEC 10\%) & 15 & $21^{\mathrm{b}} \pm 5.09$ \\
\hline
\end{tabular}

Based on data analysis, the level of maturation identified through GV observation showed significant differences ( $\mathrm{p}<0.05)$ between control group and treatment 1 (OFP 10\%), but there was no significant differences ( $p>0.05$ ) in $10 \%$ OEC addition with negative control group. Furthermore, observations of maturation rate based on BVBD percentage showed similar results to GVBD, M1 and M2 observations. Based on the statistical data it can be concluded that OFP supplementation in concentration of $10 \%$ in maturation media provided a better level of maturation compared to OEP supplementation in concentration of $10 \%$ in TCM 199. Oocyte maturation method employed in many laboratories uses TCM-199 media, 
supplemented with $10 \%$ fetal calf serum (FCS) and gonadothropin hormone (FSH, LH) which is then incubated in a $\mathrm{CO} 2$ incubator at a temperature of $38.5^{\circ} \mathrm{C}$ for 24 hours. After incubation, the oocytes are already mature and first polar body is emerging and ready for fertilization. Ideally, more than $90 \%$ of oocyte maturation is expected to reach metaphase II.

Many factors affect oocyte maturation process in vivo. In addition to hormonal factors, apparently there are local factors in the oviduct, known as local cytokine and allegedly contained in the oviduct fluid ${ }^{14}$ and partly secreted by oviduct epithelium.

Studies on compounds/substances supplementation into maturation media have been frequently conducted in order to produce good post-maturation oocyte quality, ${ }^{7,10}$ one of which comes from oviduct fluid. The liquid in mammals oviduct provides biological environment for fertilization and early stage of embryos cleavage. The result is the formation of luminal environment consisting of macromolecules and proteins derived from serum transudate or epithelial secretion. In the last decade it is known that the oviduct and oviduct epithelial secretion plays an important role in fertilization.

This study also shows that OFP supplementation in a concentration of $10 \%$, through GV, GVBD, M1, and M2 observation, provides significant maturation rate compared to that with OEP supplementation in a concentration of $10 \%$. Nevertheless, this study did not analyze in detail any of the compounds contained in OFPdan OEP.

Detection and analysis of proteins synthesized and secreted from oviduct epithelium plays a role in creating specific microenvironment in the lumen of the oviduct for ovum maturation, sperm capacitation, gamete and embryo transport, fertilization and early embryo cleavage. This complex function depends on the activity of the epithelium, both secretory and ciliated and non-ciliated, that line the oviduct mucosa. The function of these cells are regulated by ovarian steroids, estrogen and progesterone. It is also not unrelated to the estrus phase experienced by females. ${ }^{15}$

\section{References}

1. Syaiful, F.L., Zesfin, B. P., Saladin, R., Jaswandi and Hendri. 2010. Efektivitas Manipulasi Berbagai Ko-Kultur Sel pada Sistem Inkubasi CO2 5\% untuk Meningkatkan Produksi Embrio Sapi Secara In Vitro. JITV Vol. 15 No. 1 Th. 2010: 56-62.

2. Putro, P.P. 1993. Petunjuk Laboratorium Fertilisasi In Vitro. Pusat Antar UniversitasBioteknologi. UGM. Yogyakarta.

3. Fatchiyah, F.G. Ciptadi, M.S. Djati dan S. Wahyuningsih. 2000. Penambahan FBS dan EGS pada Media Kultur Maturasi In Vitro (IVM) Oosit Kambing LokalPE. Natural. J. 4 (3): 52-55.

4. Susilorini T.E, Kuswati N. (2003). "Penggunaan Serum Sapi, Cairan Folikel dan Ekstrak Hipofise Dalam TCM-199 Untuk Maturasi Oosit Sapi”. Jurnal Ilmu-Ilmu Hayat (Life Sciences). VOL. 15-NO.1. Hlm.53-58.

5. Boediono A. 2005. Produksi embrio kembar identik melalui bedah mikro pada embrio kambing hasil in vitro. Jurnal Veteriner 6(2): 3946.
6. Besenfelder, Havlicek V., Brem G., 2012. In: Embyo Technology, Constantine the Philosopher University in Nitra, Faculty of Natural Sciences.

7. Mendes, J.O.B. Jr, Burns, P.D., De la TorreSanchez, J.F. and Seidel, G.E. Jr (2003) Effect of heparin on cleavage rates and embryo production with four bovine sperm preparation protocols. Theriogenology60, 331-340. Merks, J.W.M., Cucro-Steverink, D.

8. Merton, J.S., de Roos, A.P.W., Mullaart, E., de Ruigh, L., Kaal, L., Vos, P.L.A.M. and Dieleman, S.J. (2003) Factors affecting oocyte quality and quantity in commercial application of embryo technologies in the cattle breeding industry. Theriogenology59, 651-674.

9. Situmorang, P dan E. Triwulaningsih. 2004. Aplikasi dan inovasi teknologi transfer embrio (TE) untuk pengembangan sapi potong. Lokakarya Nasional Sapi Potong. pp. 95-105.

10. Fibrianto, Y.H., Pangestiningsih, T.W, Hanna, A., Airin, C. M., dan N. Rachmawati. 2009. Perbandingan pengaruh penambahan cairan folikel sapi dengan babi terhadap maturasi oosit anjing (Cannis familiaris) secara in vitro 
dari stadium estrus ovarium. J. Sain. Vet. Vol 27 No. 2.

11. Boediono, A., Y. Rusiyantono, K. Mohamad, I. Djuwita dan Y. Sukra. 1999. Produksi Embrio Kambing dengan Teknologi Maturasi, Fertilisasi dan Kultur In Vitro. Seminar Nasional Peternakan Veteriner. 258-263.

12. Kementan. 2014. Program Swasembada Daging 2014. Peraturan pemerintah.
13. Voronina, E. and G. M. Wessel. 2003. The Regulation of Oocyte Maturation. Current Topics in Developmental Biology, 58: 53-110.

14. Anguilar, J. and M. Reyley. 2005. The uterine tubal fluid: secretion, composition and biological effects. Animal Reproduction 2: 91105

15. Buhi, W.C. 2002. Characterization and Biological Roles of Oviduct-specific, Oestrogen-dependent Glycoprotein. Reproduction 123: 355-362 